\title{
Tenascin-C induces inflammatory mediators and matrix degradation in osteoarthritic cartilage
}

\author{
Lisha Patel, Weiyong Sun, Sonya S Glasson, Elisabeth A Morris, Carl R Flannery and Priya S Chockalingam
}

\begin{abstract}
Background: Tenascin-C (TN-C) is an extracellular matrix glycoprotein that is involved in tissue injury and repair processes. We analyzed TN-C expression in normal and osteoarthritic (OA) human cartilage, and evaluated its capacity to induce inflammatory and catabolic mediators in chondrocytes in vitro. The effect of TN-C on proteoglycan loss from articular cartilage in culture was also assessed.

Methods: TN-C in culture media, cartilage extracts, and synovial fluid of human and animal joints was quantified using a sandwich ELISA and/or analyzed by Western immunoblotting. mRNA expression of TN-C and aggrecanases were analyzed by Taqman assays. Human and bovine primary chondrocytes and/or explant culture systems were utilized to study TN-C induced inflammatory or catabolic mediators and proteoglycan loss. Total proteoglycan and aggrecanase -generated ARG-aggrecan fragments were quantified in human and rat synovial fluids by ELISA.

Results: TN-C protein and mRNA expression were significantly upregulated in OA cartilage with a concomitant elevation of TN-C levels in the synovial fluid of OA patients. IL-1 enhanced TN-C expression in articular cartilage. Addition of TN-C induced IL-6, PGE 2 , and nitrate release and upregulated ADAMTS4 mRNA in cultured primary human and bovine chondrocytes. TN-C treatment resulted in an increased loss of proteoglycan from cartilage explants in culture. A correlation was observed between TN-C and aggrecanase generated ARG-aggrecan fragment levels in the synovial fluid of human OA joints and in the lavage of rat joints that underwent surgical induction of OA.

Conclusions: TN-C expression in the knee cartilage and TN-C levels measured in the synovial fluid are significantly enhanced in OA patients. Our findings suggest that the elevated levels of TN-C could induce inflammatory mediators and promote matrix degradation in OA joints.
\end{abstract}

\section{Background}

Tenascin-C (TN-C) is a modular, multifunctional extracellular matrix (ECM) glycoprotein that is associated with tissue injury and repair. It was discovered originally in gliomas, muscle tissue and in the nervous system, and called by different names: myotendinous antigen, glial/mesenchymal ECM protein, cytotactin, J1 220/200, neuronectin and hexabrachion [1]. It was later found in the osteotendinous junction and superficial layers of articular cartilage $[2,3]$. The structure of TN-C comprises an amino-terminal oligomerization domain consisting of heptad repeats, multiple epidermal growth factor (EGF)-like repeats, fibronectin type III repeats (FN-III) and a carboxyl-terminal fibrinogen-like globular domain. It forms a hexameric 1.5 million Da form

\footnotetext{
* Correspondence: priya.chockalingam@pfizer.com
Tissue Repair, BioTherapeutics Research \& Development, Pfizer, Cambridge,

* Correspondence: priya.chockalingam@pfizer.com
Tissue Repair, BioTherapeutics Research \& Development, Pfizer, Cambridge, MA, USA
}

(c) 2011 Patel et al; licensee BioMed Central Ltd. This is an Open Access article distributed under the terms of the Creative Commons Attribution License (http://creativecommons.org/licenses/by/2.0), which permits unrestricted use, distribution, and reproduction in any medium, provided the original work is properly cited. through the formation of disulfide links $\mathrm{N}$-terminal to the triple-coiled coil region of two trimers [4].

$\mathrm{TN}-\mathrm{C}$ interacts with a variety of ECM molecules and cell surface receptors, thus affecting tissue architecture, tissue resilience and cell responses. It plays a major role in cell adhesion, migration, proliferation, and cellular signaling through induction of pro-inflammatory cytokines [5]. TN-C is abundantly expressed during embryogenesis and organogenesis. Its expression is highly restricted in healthy adult tissues, but reappears in the process of wound healing, regeneration, or neoplastic events [6,7]. TN-C is associated with the development of articular cartilage, but decreases markedly during maturation of chondrocytes [8,9], and almost disappears in adult cartilage $[10,11]$. In diseased conditions including osteoarthritis (OA) and rheumatoid arthritis (RA), TN-C is highly expressed in both cartilage and synovium [10-13]. A correlation between TN-C levels in 
synovial fluid and degree of cartilage degradation [14] or radiographic progression of knee OA [15] has been shown.

The proinflammatory cytokine, IL-1 plays a significant role in joint pathology, and its actions can occur through TLR4 (Toll-like receptor-4) activation [16]. Bobacz et al. confirmed the expression of TLR4 in human articular chondrocytes at both the mRNA and the protein level [17]. Lipopolysaccharides (LPS) induce catabolic effects in cartilage matrix [18]; LPS-induced activation of TLR4 in articular chondrocytes has been shown to decrease matrix biosynthesis [17]. TN-C was recently identified as an endogenous DAMP (damageassociated molecular pattern) activating TLR4 in inflammatory diseases [19]. TN-C is also reported to induce cytokine and metalloprotease (MMP) synthesis in murine synovial fibroblasts via activation of $\alpha 9$ integrins [20]. Intra-articular injection of $\mathrm{TN}-\mathrm{C}$ promoted joint inflammation in-vivo in mice, and mice that do not express $\mathrm{TN}-\mathrm{C}$ showed rapid resolution of acute joint inflammation and are protected from erosive arthritis induced by immunization and intra-articular injection of methylated BSA [19].

The objective of the current study was to compare cartilage mRNA and protein levels of TN-C under normal and OA conditions, and determine the effect of IL1 on TN-C expression in articular cartilage. We also evaluated the role of $\mathrm{TN}-\mathrm{C}$ in inducing inflammatory mediators and proteoglycan degradation in articular cartilage. TN-C levels were correlated with proteoglycan levels in the synovial fluid samples of OA patients; and the pattern of $\mathrm{TN}-\mathrm{C}$ release as compared to aggrecanase-generated ARG-aggrecan fragment release into synovial fluid was followed in a rat model of OA.

\section{Methods}

\section{Human cartilage extract and RNA preparation}

Specimens of non-OA cartilage obtained from human donors with consent had no history of joint disorders; they were received within 36 hours following autopsy (National Disease Research Interchange, Philadelphia, PA), examined macroscopically and smooth intact surfaces without OA-like lesions were harvested for protein extraction and RNA preparation. The average age of the 7 non-OA donors was 43 years with an age range of 3858 years. Specimens of OA cartilage with visible lesions were obtained with consent from patients undergoing knee replacement surgery at New England Baptist Hospital, and harvested within a few hours of surgery. The average age of the 7 OA cartilage donors was 68 years with an age range of 50-82 years. This study was performed under the approval of Pfizer's Institutional Human Ethics Committee. Cartilage slices harvested under sterile conditions were cut into explants $(6-8 \mathrm{~mm}$ width), rinsed three times in PBS, and flash frozen. Cartilage $(1 \mathrm{~g}$ each) was pulverized in a Spex Certiprep freezer mill Model $6750(15 \mathrm{~Hz} ; 2 \times 1$ min with $1 \mathrm{~min}$ pause between cycles) under liquid nitrogen for protein extraction and RNA preparation. RNA was prepared from pulverized cartilage as described [21]. For protein extraction, the powdered cartilage was immediately suspended in $10 \mathrm{ml}$ of $4 \mathrm{M}$ guanidine $\mathrm{HCl}, 50 \mathrm{mM}$ sodium acetate pH 5.8 containing protease inhibitor cocktail (Calbiochem, Gibbstown, NJ) and extracted for 48 hours at $4^{\circ} \mathrm{C}$ on a rotator. The mixture was then centrifuged at 3,000 rpm for $10 \mathrm{~min}$ and the supernatant dialyzed against $20 \mathrm{mM}$ Tris- $\mathrm{HCl}, \mathrm{pH} 8.2$ (with protease inhibitors) overnight at $4{ }^{\circ} \mathrm{C}$. OA and non-OA cartilage extracts $(5 \mu \mathrm{g}$ protein equivalent) were deglycosylated with $0.15 \mathrm{U} / \mathrm{ml}$ chondroitinase ABC (Sigma, St Louis, MO), $0.15 \mathrm{U} / \mathrm{ml}$ Keratanase I and $0.0075 \mathrm{U} / \mathrm{ml}$ Keratanase II (Seikagaku America, Falmouth, MA) at $37^{\circ} \mathrm{C}$ for 3 hours. The samples were separated on a 3-8\% TrisAcetate gel (Invitrogen, Carlsbad, CA), transferred to nitrocellulose membrane and probed with anti-human Tenascin-C (EGF-like domain) antibody 4F10TT (Immuno-Biological Laboratories Co., Ltd. Japan) at 1:100 dilution followed by incubation in anti-mouse IgG (H\&L) conjugated to alkaline phosphatase (Promega, Madison, WI) at 1:3000 dilution. Detection of reactive bands was performed with NBT/BCIP substrate (Promega). Purified human TN-C protein (Millipore, Billerica, MA) was used as a positive control in the Western blot analysis. The blots were also probed with secondary antibody alone to confirm specificity of detection.

\section{Endotoxin removal}

Purified human TN-C protein (Millipore) from human glioma cell line U251 was used in the in vitro experiments. Endotoxin levels in the TN-C protein samples were measured using the Endosafe Portable Test System (Endosafe-PTS) in a cartridge, PTS 201 with a sensitivity range of 10-0.1 EU/ml (Charles River Laboratories, Wilmington, MA). The protein was taken through an endotoxin removal process using detoxigel endotoxin removal columns (ThermoFisher Scientific, Waltham, MA) following manufacturer's protocol. The endotoxin levels were measured again in the $\mathrm{TN}-\mathrm{C}$ preparation using the cartridge, PTS 2005 (5-0.05 EU/ml range sensitivity) and the Endosafe-PTS after endotoxin removal.

\section{Primary chondrocyte cultures}

Bovine and human primary chondrocytes were prepared under sterile conditions by pronase and collagenase treatments followed by filtration and centrifugation as previously described [22]. Cells were washed, resuspended in DMEM-F12 (Gibco, Carlsbad, CA), 10\% FBS (Sigma, St. Louis, MO), 1\% antimycotic-antibiotic 
solution (Sigma), and counted on a hemocytometer. Cell viability was determined by trypan blue dye exclusion, cell viability was found to be $>95 \%$. Cells were plated at 1 million/well in a 24 well tissue culture plate $(1 \mathrm{ml} /$ well) and maintained at $37^{\circ} \mathrm{C}$. The cells were serum starved overnight once they were confluent (in 3-4 days), and washed with serum free media before induction. LPS from E. coli R515 (Re) (Axxora, San Diego, $\mathrm{CA})$ at 0 to $1000 \mathrm{ng} / \mathrm{ml}$ or $\mathrm{TN}-\mathrm{C}$ protein at 0 to $10 \mu \mathrm{g} /$ $\mathrm{ml}$ was added and incubated for 48 hours at $37^{\circ} \mathrm{C}$ to study dose-dependent induction of primary chondrocytes. Heat killed TN-C that was heated at $100^{\circ} \mathrm{C}$ for 30 min, and LPS preincubated for 1 hour with polymyxin-B (PMB; Sigma, St. Louis, MO) served as negative controls for TN-C and LPS treatment, respectively. TN-C at 10 $\mu \mathrm{g} / \mathrm{ml}$ preincubated with $3 \mu \mathrm{g} / \mathrm{ml}$ PMB was also tested to confirm that the induction effects observed with TN$\mathrm{C}$ were not endotoxin related. TAK242, a specific TLR4 inhibitor [23], was synthesized at Pfizer. For TAK242 treatment, the cells were pretreated with inhibitor alone for 2 hours prior to induction with $1000 \mathrm{ng} / \mathrm{ml} \mathrm{LPS} \mathrm{or}$ $10 \mu \mathrm{g} / \mathrm{ml} \mathrm{TN}-\mathrm{C}$ in the presence of inhibitor. The media was removed after 48 hours of induction and analyzed in IL-6, nitrate, and $\mathrm{PGE}_{2}$ assays. Cells treated with $1000 \mathrm{ng} / \mathrm{ml} \mathrm{LPS}, 10 \mu \mathrm{g} / \mathrm{ml} \mathrm{TN}-\mathrm{C}$ or $5 \mathrm{ng} / \mathrm{ml} \mathrm{IL-1 \beta}$ with or without TAK242 for 48 hours were washed in PBS, and lysed in lysis buffer for RNA preparation using RNAeasy kit (Qiagen, Valencia, CA) following the manufacturer's protocol.

\section{Cartilage explant cultures}

Articular cartilage explant discs were harvested under sterile conditions from young bovine metacarpal phalangeal joints (Research 87, Hopkinton, MA). Briefly, fullthickness plugs were punched using a $8 \mathrm{~mm}$ cork borer and cartilage discs were generated by slicing $1 \mathrm{~mm}$ thick sections from the articular surface of the plugs. Discs were rinsed in PBS and subsequently cultured in medium. The medium consisted of Dulbecco's Modified Eagle's medium (JRH Biosciences, Lenexa, KS), $50 \mu \mathrm{g} / \mathrm{ml}$ ascorbic acid (Wako, Osaka, Japan), $10 \mathrm{mM}$ HEPES (Mediatech, Herndon, VA), 2 mM L-glutamine (Mediatech), antibiotic-antimycotic solution (Sigma). Discs were cultured for 5 days with one media change in a $37^{\circ}$ $\mathrm{C}$ and $5 \% \mathrm{CO}_{2}$ environment to equilibrate the tissue prior to treatment. Following equilibration, 3 discs ( $100 \mathrm{mg} /$ well) were weighed and placed in 24-well tissue culture plate in $1 \mathrm{ml}$ medium with or without 1 or $10 \mathrm{ng} / \mathrm{ml}$ of IL-1 $\alpha$ (Sigma, St Louis, MO) for 48 hours for the first study. The media was tested for TN-C levels, and RNA prepared from cartilage discs for TN-C taqman analysis. For the second study, explants were

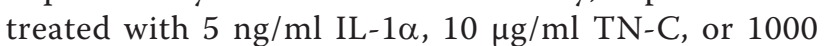
$\mathrm{ng} / \mathrm{ml}$ LPS with or without TAK242 $(0.01,0.1$, or 1 $\mu \mathrm{M})$. For TAK242 effects, explants were pre-treated with the inhibitor for 2 hours prior to induction in the presence of inhibitor. The media was removed for the analysis of proteoglycan release after 48 hours of induction.

\section{Synovial fluid samples}

Neat human knee joint synovial fluids from patients with end stage osteoarthritis $(\mathrm{OA} ; \mathrm{n}=8: 4$ males and 4 females; 50-83 years old) were obtained from NEBH, and synovial fluids from knee-healthy reference subjects (Ref; $\mathrm{n}=8: 5$ males and 3 females; $45-56$ years old) were from NDRI or Northland labs with patient consent. The OA group included 7 synovial fluids of the same donors from whom cartilage samples were used for $\mathrm{TN}-\mathrm{C}$ protein and mRNA expression. Representative $\mathrm{OA}$ and reference synovial fluids $(15 \mu \mathrm{l}$ each) from the above set were treated with $10 \mathrm{U}$ of hyaluronidase (Sigma) at RT overnight and subjected to Western blot analysis with anti-human Tenascin-C (EGF-like domain) antibody 4F10TT as described above for cartilage extracts. The blots were probed with secondary antibody alone to confirm specificity of detection.

Male Lewis rats weighing approximately 300 grams were obtained from Charles River Laboratories (Wilmington, MA). The rats underwent medial meniscal surgery in the right knee to induce joint instability leading to cartilage degeneration as described [24]. The animals were euthanized at different times after surgery (4 days, $1 \mathrm{wk}, 2 \mathrm{wks}$, and $3 \mathrm{wks} ; \mathrm{n}=10$ animals/time point). Synovial fluid lavages and serum were collected. Five naïve animals per time point were also included. Serum and synovial fluid lavage urea levels in each rat were used to correct TN-C, proteoglycan, and ARG-aggrecan values for dilution. This study was performed under the approval of Pfizer's Institutional Animal Care and Use Committee.

\section{Biochemical assays}

TN-C was measured in cartilage extracts, conditioned media, and synovial fluid samples using the TN-C Large ELISA kit (Immuno-Biological Laboratories Co., Ltd. Japan). The ELISA uses anti-TN-C 19C4MS monoclonal antibody against the FNIII-C domain for capture, and HRP conjugated anti-TN-C 4F10TT mouse monoclonal antibody against the EGF domain for detection. 4F10TT binds an epitope from the EGF domain and recognizes both the small and large TN-C variants. 19C4MS binds an epitope of the FNIII-C domain and recognizes large variants. The characteristics of these antibodies have been described elsewhere $[15,25]$. TN-C standard in the kit was run at 0-24 $\mathrm{ng} / \mathrm{ml}$ for a standard curve. Samples were appropriately diluted in PBS and assayed in the TN-C ELISA using manufacturer's protocol. TN-C 
standard or human synovial fluid samples incubated in PBS- or mouse IgG-coated wells were included as controls. To confirm specificity of TN-C detection, aggrecan, a major cartilage proteoglycan purified from human cartilage as described [26] was tested at various concentrations in the assay as a negative control. To further confirm specificity of detection in synovial fluid, two human synovial fluids were immunodepleted of TN-C using anti-TN-C 4C8MS monoclonal antibody (Immuno-Biological Laboratories Co.) against the FNIIIB domain [27], or anti-human TN-C BC-24 (Abcam, Cambridge, MA) against the EGF domain, and then analyzed in the ELISA. Protein-G Dynabeads (Invitrogen) were used following manufacturer's protocol for immunoprecipitation $(20 \mu \mathrm{g}$ antibody; $200 \mu \mathrm{l}$ of synovial fluid), Mouse IgG was used as a negative control in immunodepletion experiments. In order to determine spike-in recovery of $\mathrm{TN}-\mathrm{C}$, two human synovial fluids diluted to $1: 100,1: 200$, or $1: 400$ were spiked in with TN-C standard at a final concentration of 5 or $10 \mathrm{ng} / \mathrm{ml}$ and analyzed in the ELISA.

Protein was quantified using the microplate Bradford protein assay (Thermo Scientific, Rockford, IL). Cell toxicity was determined in primary cell and explant cultures by measuring lactate in the conditioned media using a lactate assay (Trinity biotech, St. Louis, MO). Prostaglandin $\mathrm{E}_{2}\left(\mathrm{PGE}_{2}\right)$ release was measured using a PGE $\mathrm{PLISA}_{2}$ (R\&D Systems, Minneapolis MN). Measurement of nitrate concentrations was performed using a nitrate/ nitrite colorimetric assay kit (Cayman Chemical Company, Ann Arbor, MI). Human chondrocyte conditioned media were screened using a human proinflammatory 7plex MSD tissue culture kit (Meso Scale Discovery, Gaithersburg, Maryland). Human IL-6 and IL-8 were measured individually using MSD human cytokine assay tissue culture kits (Meso Scale Discovery). The proteoglycan content in bovine explant conditioned media was measured as sulfated glycosaminoglycan (sGAG) by a colorimetric assay with dimethylmethylene blue (Serva, Heidelberg, Germany) [28]. Proteoglycan levels in human synovial fluids were determined by the sGAG assay (Kamiya Biomedical Company, Seattle, WA) [29]. ARGaggrecan fragments in synovial fluids were measured in an ELISA developed at Pfizer [26].

\section{Gene expression assays}

Taqman gene expression assays were done using onestep RT-PCR reagents and Assay on Demand primerprobe sets (Applied BioSystems, Foster City, CA) following manufacturer's protocol. For analyzing bovine samples, GAPDH (Bt03210913_g1), and ADAMTS4 (Bt03224693_m1) primer/probe sets were used. For the human samples, GAPDH (Hs99999905_m1), ADAMTS4 (Hs00192708_m1), ADAMTS5 (Hs00199841_m1), and
TN-C (Hs01115665_m1) primer/probe sets were used. 100 ng RNA per sample was tested in duplicates and results averaged.

\section{Statistical analysis}

One-way Analysis of Variance (ANOVA) of log transformed values was performed for TN-C and ARG-aggrecan levels in human and rat joint fluids to test for statistical significance. Student's t-test was performed for the TN-C protein and mRNA expression studies and in vitro inhibition studies to test for significance. Spearman rank order was used for correlation analysis.

\section{Results}

TN-C mRNA expression was significantly upregulated by approximately 6 -fold $(\mathrm{p}=0.02)$ in OA relative to non-OA cartilage (Figure 1A). An ELISA, which measures large splice variants of TN-C (TN-C Large) [30], was then used to measure TN-C protein levels. TN-C standard or samples plated on PBS- or mouse IgG coated wells did not produce any optical density (OD) values in the ELISA confirming specific binding of TN$\mathrm{C}$ to $19 \mathrm{C} 4 \mathrm{MS}$-coated plates. Aggrecan tested as a negative control did not produce signal further confirming the specificity of detection. OA cartilage $(n=7)$ had a mean of $5.79 \mathrm{ng} \mathrm{TN}-\mathrm{C}$ per $\mu \mathrm{g}$ total protein, which was significantly higher (approximately 8 -fold; $\mathrm{p}=0.0006$ ) than the levels in non-OA cartilage $(n=7)$ which gave a mean of $0.69 \mathrm{ng}$ per $\mu \mathrm{g}$ total protein (Figure 1B). In the Western immunoblot analyses of representative cartilage extracts, we also observed increased $\mathrm{TN}-\mathrm{C}$ levels in $\mathrm{OA}$ cartilage extracts (Figure 1C). Two large variants of 350 and $240 \mathrm{kD}$ molecular weight, and a small variant at $210 \mathrm{kD}$ were observed in OA cartilage. The non-OA cartilage extracts had only the $240 \mathrm{kD}$ large variant and the small $210 \mathrm{kD}$ variant.

Purified TN-C protein (Millipore) consisting of large variants was tested for endotoxin levels using the Endosafe-PTS that utilizes existing FDA-licensed LAL (Limulus amaebocyte lysate) formulations loaded into a test cartridge. The level measured prior to endotoxin removal was 8.0 endotoxin units $(\mathrm{EU}) / \mathrm{mg}$ protein. After passing the protein through detoxigel endotoxin removal columns, the levels dropped to $<0.05 \mathrm{EU} / \mathrm{mg}$ protein in the Endosafe-PTS assay. When human primary chondrocytes were treated with varying concentrations of TN-C or LPS (1-10 $\mu \mathrm{g} / \mathrm{ml}$ TN-C; 0.1-1000 ng/ml LPS) and conditioned media samples screened using the proinflammatory 7-plex MSD kit (for IFN- $\gamma$, IL-1 $\beta$, IL-6, IL-8, IL-10, IL-12p70, and TNF $\alpha$ ), only IL-6 and IL-8 were detected and found to be significantly induced by TN-C or LPS treatments (data not shown). Individual IL- 6 and IL-8 MSD tissue culture kits were used for further confirmation. 

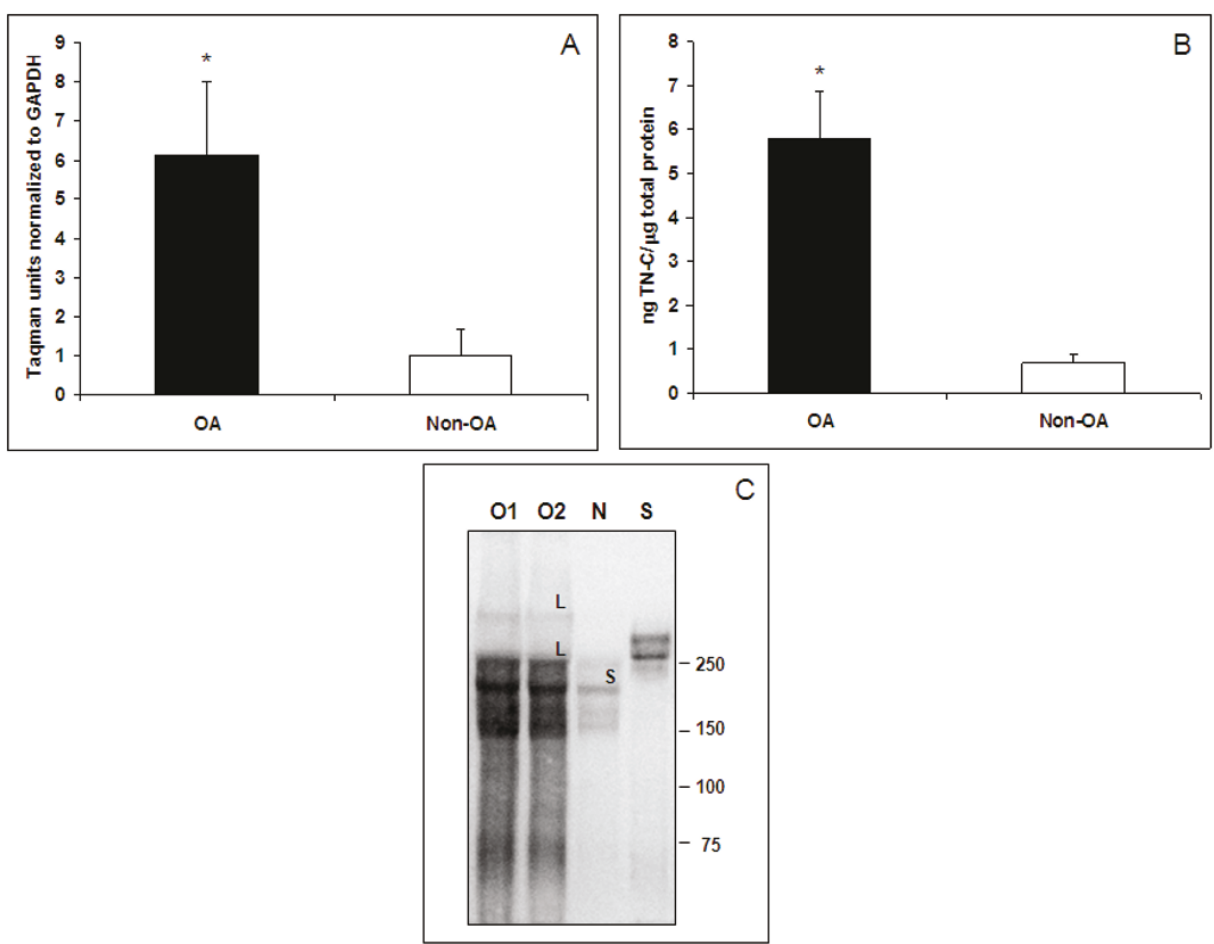

Figure $1 \mathrm{TN}-\mathrm{C}$ expression in $\mathrm{OA}$ vs. non-OA human cartilage. A, mRNA expression of TN-C in human cartilage expressed as Tagman units normalized to GAPDH. Non-OA has been set to 1. $\mathrm{n}=7$ donors each group; error bars indicate SD; $\mathrm{p}=0.02$. B, Protein expression of TN-C in cartilage as measured in the TN-C Large ELISA. $N=7$ donors each group; error bars indicate SD; $p=0.0006$. C, Representative OA and non-OA cartilage extracts (5 $\mu \mathrm{g}$ protein) separated on a 3-8\% tris-acetate gel, transferred, and probed with anti-TN-C (EGF-like domain) antibody, 4F10TT that detects all forms of TN-C. Lanes are $\mathrm{O}=\mathrm{OA} ; \mathrm{N}=$ Non-OA; $\mathrm{S}=$ standard human TN-C protein (Millipore). Bands are marked as $\mathrm{L}=$ large variant and $\mathrm{S}=$ small variant.

LPS tested at 0.1 to $1000 \mathrm{ng} / \mathrm{ml}$ induced IL- 6 and IL-8 release from human primary chondrocytes dose-dependently resulting in 20-170 fold induction of IL-6 at 1 to $1000 \mathrm{ng} / \mathrm{ml} \mathrm{LPS}$, and 15-60 fold induction of IL-8 at 10 to $1000 \mathrm{ng} / \mathrm{ml}$ LPS. No significant increase over control was observed for IL-6 at $0.1 \mathrm{ng} / \mathrm{ml} \mathrm{LPS}$; and for IL-8 at 0.1 and $1 \mathrm{ng} / \mathrm{ml}$ LPS (Figure 2A). IL-6 was followed up in further experiments with chondrocytes and explants. A dose dependent inhibition of IL- 6 release by PMB was observed; $100 \%$ inhibition of IL-6 release was seen at $1 \mu \mathrm{g} / \mathrm{ml}$ PMB (Figure 2B). $1000 \mathrm{ng} / \mathrm{ml}$ LPS that was pre-incubated with $3 \mu \mathrm{g} / \mathrm{ml} \mathrm{PMB}$ served as a negative control for LPS treatment in further experiments. Nitrate release was induced 2-10 fold (Figure 2C) and $\mathrm{PGE}_{2}$ release increased $350-1750$ fold in a dose dependent fashion when tested at 1 to $1000 \mathrm{ng} / \mathrm{ml}$ LPS. There was no significant change in the release of nitrate and $\mathrm{PGE}_{2}$ at $0.1 \mathrm{ng} / \mathrm{ml}$ LPS (Figure 2D).

Addition of TN-C protein ( 1 or $10 \mu \mathrm{g} / \mathrm{ml})$ to human chondrocyte cultures induced IL-6, IL-8, $\mathrm{PGE}_{2}$ and nitrate in a dose dependent manner (Figure 3). TN-C treatment resulted in an approximately 160- and 230fold increase in IL-6 release; 80- and 120-fold increase in IL-8 release (Figure 3A); 3- and 8-fold increase in nitrate release (Figure 3B); and 130 - and 600 -fold increase in $\mathrm{PGE}_{2}$ (Figure $3 \mathrm{C}$ ) release at 1 and $10 \mu \mathrm{g} / \mathrm{ml}$, respectively. TN-C at $10 \mu \mathrm{g} / \mathrm{ml}$ pretreated with $3 \mu \mathrm{g} / \mathrm{ml}$ PMB did not show any reduction in IL-6, IL-8, nitrate and $\mathrm{PGE}_{2}$ release. $10 \mu \mathrm{g} / \mathrm{ml}$ heat killed $\mathrm{TN}-\mathrm{C}$ served as a negative control in this experiment and did not show induction of IL-6, IL-8, PGE 2 , or nitrate (Figure 3). The results from $\mathrm{PMB}$ treated $\mathrm{TN}-\mathrm{C}$ and heat killed TN-C confirmed that the effects observed were endotoxin independent.

Induced IL-6, $\mathrm{PGE}_{2}$, and nitrate release with $1000 \mathrm{ng} /$ $\mathrm{ml}$ LPS or $10 \mu \mathrm{g} / \mathrm{ml}$ TN-C treatment was dose-dependently inhibited by TAK242. TAK242 at $1 \mu \mathrm{M}$ resulted in complete inhibition of LPS or TN-C induced release of IL-6, $\mathrm{PGE}_{2}$ and nitrate (Figure 4). Lactate concentrations in the media ( $\geq 85 \%$ lactate compared to control wells) confirmed that inductions and inhibitor treatments were tolerated by the cells at the concentrations used.

ADAMTS4 mRNA expression in bovine chondrocytes was up regulated 28 - and 25 -fold when treated with 10 $\mu \mathrm{g} / \mathrm{ml} \mathrm{TN}-\mathrm{C}$ and $1000 \mathrm{ng} / \mathrm{ml}$ LPS, respectively. 

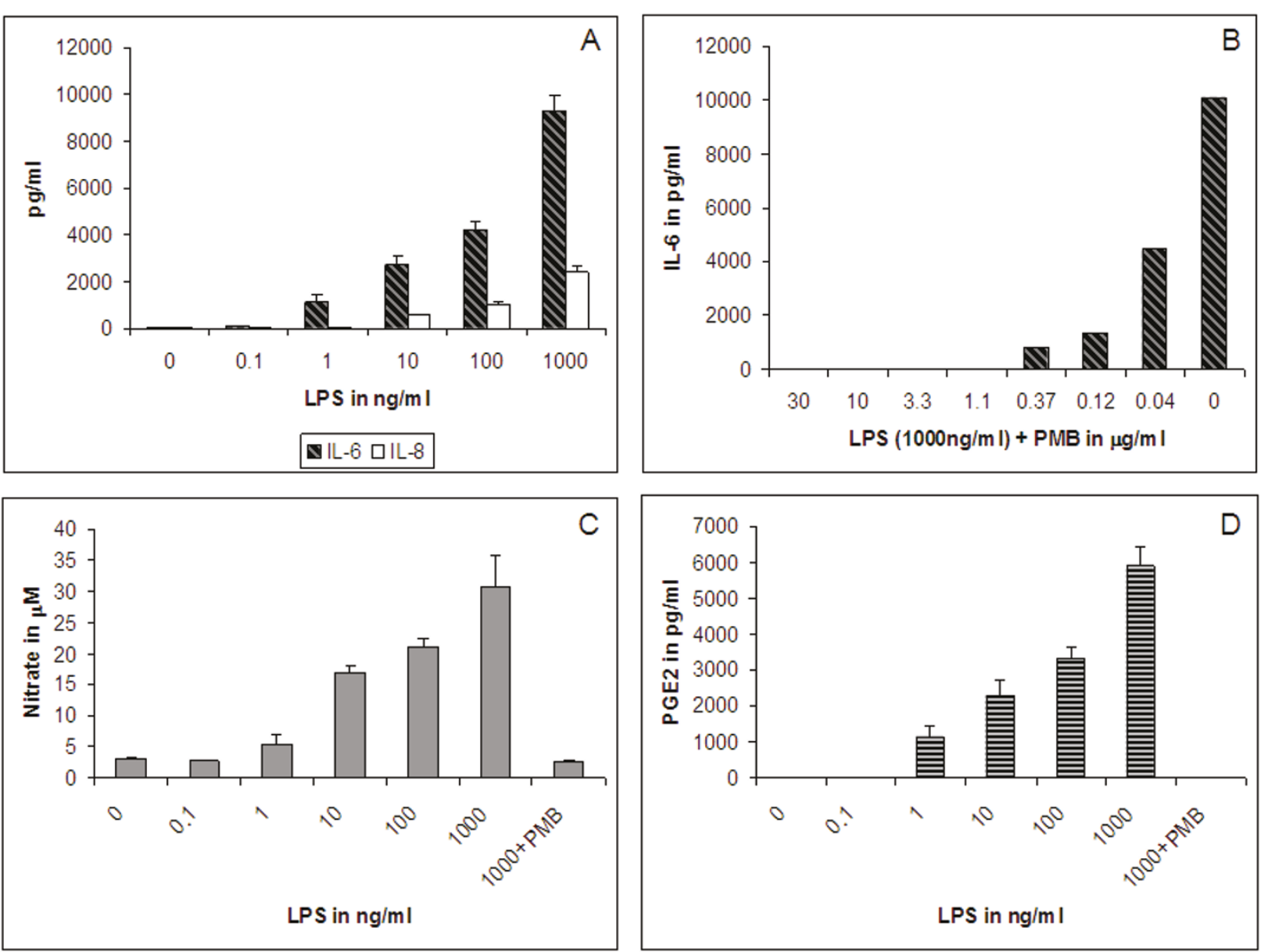

Figure 2 LPS induction of primary human chondrocytes. Release of A, IL-6 and IL-8; C, nitrate; and D, PGE $E_{2}$ from cultured human chondrocytes treated with 0-1000 ng/ml LPS for 48 hours. B, Dose dependent inhibition of LPS (1000 ng/ml) induced IL-6 release by polymyxin-B (PMB). PMB was added at $3 \mu \mathrm{g} / \mathrm{ml}$ in $C$ and D. The error bars indicate SD of averaged treatment results (duplicate wells) from 3 donors.

Upregulation of ADAMTS4 by TN-C or LPS was dosedependently suppressed by TAK242 (Figure 5A). Similarly, ADAMTS4 mRNA expression was upregulated 8and 20-fold in human primary chondrocytes when treated with $10 \mu \mathrm{g} / \mathrm{ml} \mathrm{TN}-\mathrm{C}$ and $1000 \mathrm{ng} / \mathrm{ml}$ LPS, respectively. IL- $1 \beta$ at $5 \mathrm{ng} / \mathrm{ml}$ that was used as a positive control resulted in 29-fold up regulation of ADAMTS4 in human chondrocytes. (Figure 5B). In contrast to ADAMTS4, ADAMTS5 did not show any significant changes with TN-C, LPS or IL-1 $\beta$ treatment. Heat killed $\mathrm{TN}-\mathrm{C}$ at $10 \mu \mathrm{g} / \mathrm{ml}$ and PMB treated LPS at $1 \mu \mathrm{g} / \mathrm{ml}$ served as negative controls and did not cause significant upregulation of ADAMTS4.

IL- $1 \alpha$ added at 0,1 , and $10 \mathrm{ng} / \mathrm{ml}$ to bovine explant cultures increased TN-C protein in the cartilage and also stimulated the release of $\mathrm{TN}-\mathrm{C}$ into the conditioned media in a dose-dependent manner (Figure 6A). The increase in $\mathrm{TN}-\mathrm{C}$ protein levels correlated with mRNA expression in the cartilage (Figure 6B).
Proteoglycan loss was induced as measured by sGAG release into the conditioned media of bovine explants following $10 \mu \mathrm{g} / \mathrm{ml} \mathrm{TN}-\mathrm{C}$ or $1000 \mathrm{ng} / \mathrm{ml}$ LPS treatment, which was similar to the loss due to $5 \mathrm{ng} / \mathrm{ml} \mathrm{IL-1 \alpha}$ induction (Figure 6C). IL-1 $\alpha$ resulted in approximately $20 \%$ loss of sGAG from bovine cartilage in 48 hours. TN-C showed a similar percentage release, whereas, the release with LPS was slightly higher at approximately $30 \%$ loss. TAK242 (at 0.1 and $1 \mu \mathrm{M}$ ) dose dependently reversed the loss of proteoglycan due to TN-C and LPS treatments, but did not affect IL-1 $\alpha$ induced proteoglycan release (Figure 6C).

Human synovial fluids depleted of $\mathrm{TN}-\mathrm{C}$ with antiTN-C antibodies prior to testing showed $100 \%$ loss of signal in the ELISA confirming the specificity of detection in synovial fluids. The mean spike-in recovery of $\mathrm{TN}-\mathrm{C}$ at three different dilutions tested was $89 \%$ with a range of $78-97 \%$. TN-C level measured in human OA synovial fluids $(\mathrm{n}=8)$ gave a mean of $380 \mathrm{ng} / \mathrm{ml}$ 

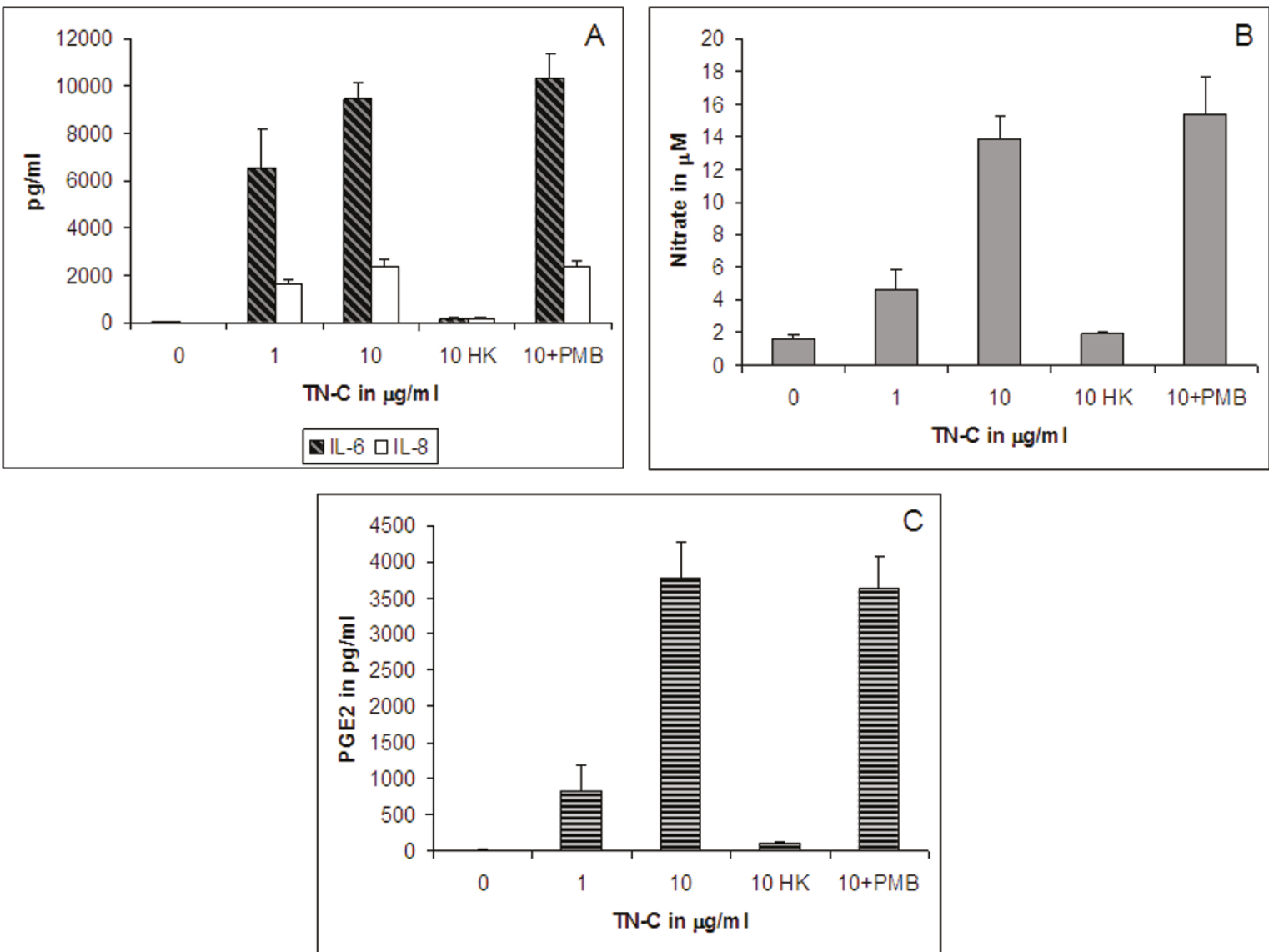

Figure $3 \mathrm{TN}-\mathrm{C}$ treatment of primary human chondrocytes. Release of $\mathrm{A}, \mathrm{IL}-6$ and IL-8; B, nitrate; $\mathrm{C}, \mathrm{PGE} \mathrm{E}_{2}$ from cultured human chondrocytes treated with $0-10 \mu \mathrm{g} / \mathrm{ml} \mathrm{TN}-\mathrm{C}$ for 48 hours. HK- heat killed. $10 \mu \mathrm{g} / \mathrm{ml}$ heat killed TN-C served as a negative control. The error bars indicate SD of averaged treatment results (duplicate wells) from 3 donors.

(range: $107-817 \mathrm{ng} / \mathrm{ml}$ ), whereas, the mean of TN-C in the reference synovial fluids was $90 \mathrm{ng} / \mathrm{ml}$ (range: 44$218 \mathrm{ng} / \mathrm{ml}$ ) giving a significant 4.2-fold higher release in the OA group as compared to the healthy reference controls $(\mathrm{p}=0.001)$. Figure $7 \mathrm{~A}$ shows the results of Western immunoblot analysis of representative OA and non-OA synovial fluid samples using anti-TN-C antibody. As in the OA cartilage extract, $350 \mathrm{kD}$ and $240 \mathrm{kD}$ large TN-C variants and the $210 \mathrm{kD}$ small variant were present in the OA synovial fluids. TN-C was present at insignificant levels in non-OA reference fluids. Our Western immunoblot analysis results correlated with the TN-C bands reported earlier in OA synovial fluids [14]. Upregulation of TN-C mRNA and protein in the cartilage correlated significantly with a simultaneous increase in the synovial fluid; the correlation analysis of these factors tested in the same OA patients have been summarized in Table 1.

A trend towards correlation was observed when TN-C levels were correlated to aggrecanase generated ARG- aggrecan or total proteoglycan in human synovial fluid samples tested (Figure 7B \&7C). In the rat meniscal tear model, there was a significant 107 -fold increase in TN-C release at 4 days in surgery knees compared to no surgery contralateral left controls or the knees of naïve animals, the fold increase dropped to 77-, 20- and 12-fold increase at 1-, 2- and 3-wks after joint instability induction, respectively. The trend of $\mathrm{TN}-\mathrm{C}$ release into the synovial fluids followed the release of ARG-aggrecan in these animals; ARG-aggrecan of rat joint fluids showed a significant 4 fold increase in the unstable right knees at 4 days and 1 wk after surgery as compared to un-operated contra-lateral left knees or naïve animals (left and right knees), the fold increase dropped gradually at 2 and 3 wks post surgery but was significantly higher than the controls (Figure 8A). There was a very significant correlation $\left(r_{\mathrm{s}}=0.92\right.$ and $\left.\mathrm{p}=<0.0001\right)$ when the TN-C levels in these samples ( $n=40$; fluids from left contra lateral and right surgery knees of 5 animals per time point) were correlated to ARG-aggrecan levels (Figure 8B). 

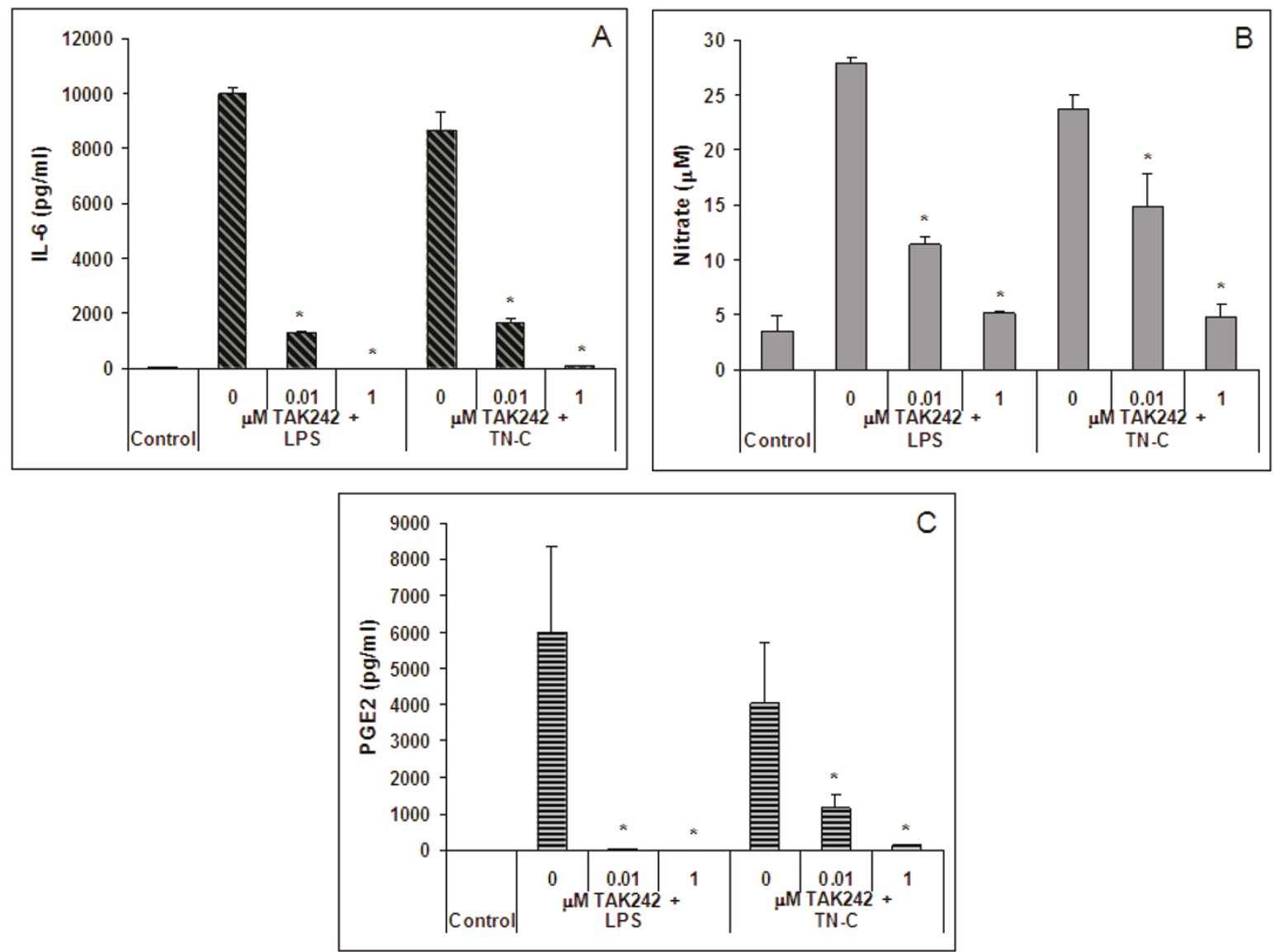

Figure 4 Effect of TAK242 on LPS or TN-C induced changes in primary human chondrocytes. Human chondrocytes were induced with 1000 $\mathrm{ng} / \mathrm{ml}$ LPS or $10 \mu \mathrm{g} / \mathrm{ml} \mathrm{TN}-\mathrm{C}$ for 48 hours. TAK242 was present 2 hours prior to induction and during the induction period. TAK242 effects on TN-C or LPS induced A, IL-6; B, nitrate; and C, PGE 2 release. The error bars indicate SD of averaged treatments (duplicate wells) from 3 donors. * indicates $p<0.05$.

\section{Discussion}

In the current study, we found a concomitant upregulation of TN-C mRNA and protein in the cartilage along with increased TN-C in the synovial fluid of OA patients. We have demonstrated a novel role for increased TN-C levels in the OA joint in promoting proteoglycan loss in addition to mediating inflammatory signals, which is supported by a correlation between $\mathrm{TN}-\mathrm{C}$ levels in the knee synovial fluid and proteoglycan loss from the articular cartilage in human and rat joints.

In musculoskeletal tissues, the factors regulating the expression of TN-C are IL-1 $\beta$ [31], tumor necrosis factor- $\alpha$ (TNF $\alpha)$ [31], transforming growth factor- $\beta$ (TGF $\beta$ ) [32], and basic fibroblast growth factor (bFGF) [33], all of which are present at increased levels in the joints of patients with OA compared with those of normal patients [34]. A range of TN-C variants with mass from 350 to $210 \mathrm{kD}$ are generated by alternative splicing of FN (III) A-D repeats of TN-C RNA [35]. Studies have shown that $\mathrm{TN}-\mathrm{C}$ is localized in articular cartilage from OA patients at the extracellular matrix underneath the surface and pericellular compartment of the chondrocytes $[10,11]$. Chondrocytes also produce both large and small variants during embryogenesis and development and provide a cellular source of TN-C in the synovial fluid $[2,9]$. We observed that both large (350 and $240 \mathrm{kD})$ and small $(210 \mathrm{kD})$ variants were abundant in OA cartilage extracts and synovial fluids when compared to non-OA samples. Our findings agree with an earlier report where all $\mathrm{TN}-\mathrm{C}$ variants were found to increase in the synovial fluid with advancing stages of cartilage degradation [14]. Western blotting revealed degraded fragments of $\mathrm{TN}-\mathrm{C}$ of molecular weight lower than $200 \mathrm{kD}$ in OA cartilage and synovial fluid (Figure 1C \&7A) that could be MMP generated [36]. The large variants are known to be more susceptible to MMP cleavage, such as MMP-2 and MMP-7, than the small variant [36]. This is evidenced by the relatively lower 

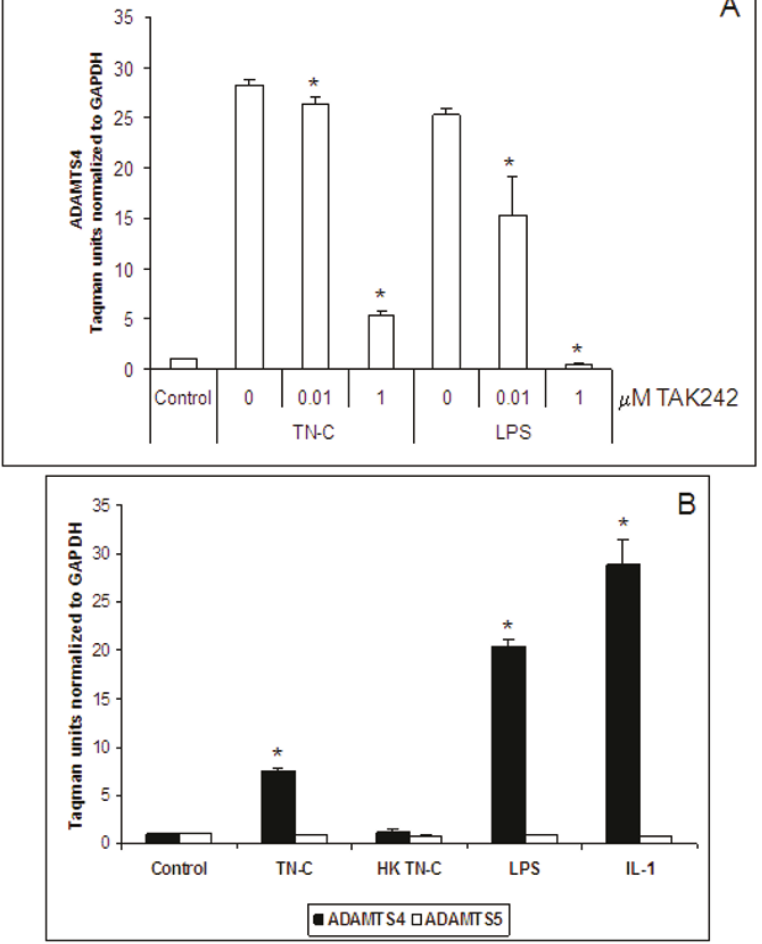

Figure $5 \mathrm{TN}-\mathrm{C}$ or LPS treatment and ADAMTS expression in primary chondrocytes. A, Bovine chondrocytes were induced with $10 \mu \mathrm{g} / \mathrm{ml} \mathrm{TN}-\mathrm{C}$ or $1000 \mathrm{ng} / \mathrm{ml}$ LPS for 48 hours with or without TAK242. TAK242 was present 2 hours prior to induction and during the induction period. B, Human chondrocytes were induced with 10 $\mu \mathrm{g} / \mathrm{ml} \mathrm{TN}-\mathrm{C}, 1000 \mathrm{ng} / \mathrm{ml}$ LPS, or $5 \mathrm{ng} / \mathrm{ml} \mathrm{IL-1 \beta}$ for 48 hours. Cells were lysed, RNA prepared and taqman assays performed with $50 \mathrm{ng}$ RNA/well. HK $=$ heat killed. ADAMTS $=$ A Disintegrin And Metalloproteinase with Thrombospondin Motifs. The error bars indicate SD of treatments done in triplicates, each RNA sample from treatments/wells was tested in duplicates in the Taqman assay and results averaged. ${ }^{*} p<0.05$.

intensity of the $350 \mathrm{kD}$ large variant in $\mathrm{OA}$ cartilage and synovial fluids. IL $\alpha$ increased TN-C levels in cartilage in culture as well as its release into the conditioned media indicating enhanced synthesis of TN-C by chondrocytes in response to inflammatory stimuli, this is in agreement with an earlier finding on IL $\beta$ induced TN-C in human cartilage [37].

LPS and other microbial components initiate signal transduction through TLR4, resulting in the release of inflammatory cytokines. TLR4 also binds to matrix components that include heparin sulfate, fibronectin, biglycan, and hyaluronan [38]. TN-C was recently added to the list of endogenous activators of TLR4 [19]. Signal transduction through TLR4 leads to the activation of transcription factors, and in turn controls the expression of proinflammatory cytokines, chemokines, and MMPs $[39,40]$. Expression of TLR4 in human OA chondrocytes

and cartilage in our study was confirmed by qPCR (data not shown). Expression of TLR4 and its adaptors have been reported also in human OA synovium [41]. Synovial tissue from OA stifle dog joints that underwent cranial cruciate ligament transaction was shown to have significantly higher TLR4 gene and protein expression as compared to the non-OA contralateral joints [42].

$\mathrm{TN}-\mathrm{C}$ levels measured in the eight human synovial fluids (based on data availability for both TN-C and ARG-aggrecan levels) included in the study ranged from $0.11-0.82 \mu \mathrm{g} / \mathrm{ml}$. However, we have measured levels up to $5 \mu \mathrm{g} / \mathrm{ml}$ in several other human OA synovial fluids tested. TN-C in dog synovial fluid after anterior cruciate ligament transection (ACLT) also went up to $5 \mu \mathrm{g} / \mathrm{ml}$ similar to human OA samples (data not shown). A dose of $1-10 \mu \mathrm{g} / \mathrm{ml} \mathrm{TN}-\mathrm{C}$ was used in our in vitro experiments to keep the treatment level close to physiological levels in the joint under diseased conditions. TN-C induced inflammatory mediators including IL-6, IL-8, nitrate and PGE2 in the cartilage in vitro in a fashion similar to LPS in our study. TAK242, the TLR4 specific small molecule inhibitor binds strongly and specifically to TLR4. It inhibits TLR4 signaling by binding to Cys747 in the intracellular domain of TLR4 [43]. We used TAK242 to confirm that the role of TN-C in inducing inflammatory mediators in articular cartilage is TLR4-dependent. Our results agree with the earlier findings in human macrophages and fibroblasts from synovia of RA patients [19].

Loss of ECM from articular cartilage is a central event that leads to joint destruction in arthritic diseases. Aggrecan is a major component of the ECM responsible for weight bearing, and an important factor in the retention of collagen within matrix [44]. Aggrecanases are responsible for degrading aggrecan in articular cartilage [45]. TN-C upregulated ADAMTS4 expression in chondrocytes in vitro via TLR4 signaling that reflected in increased loss of sGAG from the cartilage matrix. We tested the effect of added LPS $(1000 \mathrm{ng} / \mathrm{ml})$ or TN-C $(10 \mu \mathrm{g} / \mathrm{ml})$ for $48 \mathrm{hrs}$ on aggrecan mRNA expression in human primary chondrocytes using Taqman assays and found no significant regulation in aggrecan expression with treatment. TN-C or LPS treatment at the above concentrations and duration also did not result in any significant change in the proliferation rate of the primary cells tested by the bromodeoxyuridine incorporation method (data not shown). Proteoglycan loss measured as sGAG might indicate regeneration of cartilage, however, lack of TN-C or LPS induced changes in the proliferation rate and in aggrecan expression suggests that the enhanced release of sGAG results from matrix degradation; this is supported by the observed upregulation of ADAMTS4 in response to TN-C or LPS treatment. ADAMTS5 did not respond to induction 


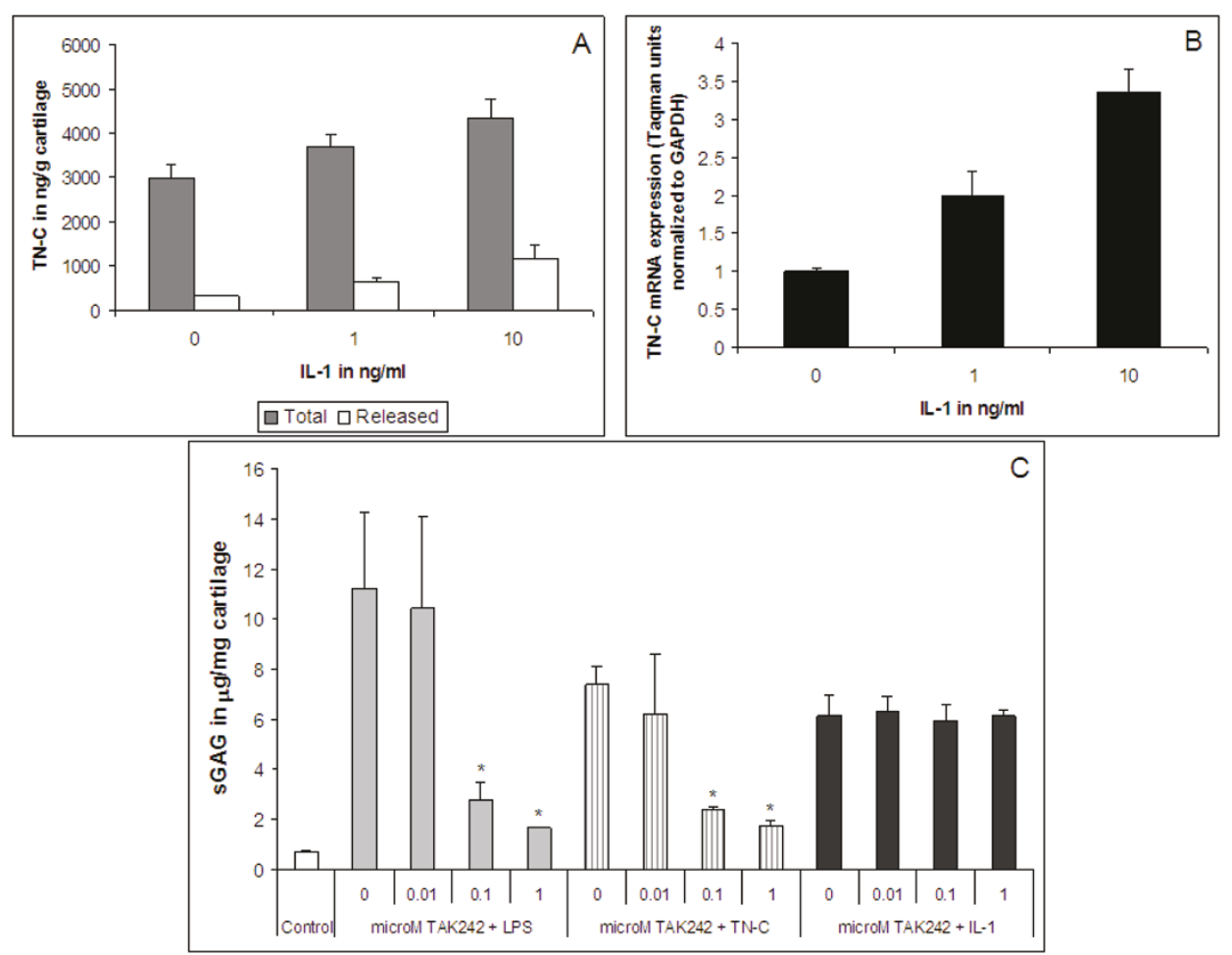

Figure 6 IL-1 $\alpha$ induced TN-C synthesis and LPS/TN-C dependent proteoglycan loss in bovine explant cultures. Bovine explants (3 discs/well) were induced with $\mathrm{LL}-1 \alpha(0,1,10 \mathrm{ng} / \mathrm{ml})$ for 48 hours and $\mathrm{A}$, cartilage extracts and conditioned media analyzed in the TN-C Large ELISA. The error bars indicate SD of treatments done in triplicates; B, cartilage RNA prepared and TN-C taqman analysis performed with 50 ng RNA/well. The error bars indicate SD of treatments done in triplicates; each RNA sample from treatments/wells was tested in duplicates in the Taqman assay and results averaged. * $p<0.05$. C, Bovine explants (3 discs/well) were induced with $1000 \mathrm{ng} / \mathrm{ml} \mathrm{LPS,} 10 \mu \mathrm{g} / \mathrm{ml}$ TN-C or $5 \mathrm{ng} / \mathrm{ml} \mathrm{IL-1} \alpha$ in the presence or absence of TAK242 $(0,0.01,0.1$, or $1 \mu \mathrm{M})$ for 48 hours and the conditioned media analyzed for sGAG content. ${ }^{*} p<0.05$.

with LPS, TN-C or IL-1 $\beta$ in our primary chondrocyte induction experiments, consistent with earlier reports on induced gene expression in cartilage $[46,47]$. However, TN-C has been shown to be upstream in the regulation of several MMPs in synovial fibroblasts [48].

Increased levels of $\mathrm{TN}-\mathrm{C}$ in the joint fluid significantly correlated with cartilage TN-C mRNA and protein levels in OA patients (Table 1). Similarly, correlating with enhanced release of TN-C from rat joints due to surgical induction of OA, we observed a slight but statistically significant upregulation of TN-C mRNA in the transcriptional profiling studies of cartilage from the knees of rats that underwent meniscal tear as compared to cartilage from the contralateral knees (34\% upregulation; $p=0.009$ ), 2 weeks post surgery. Our findings on correlation between TN-C levels and proteoglycan loss in human and rat joints are consistent with a recent report showing decreased proteoglycan staining accompanied by increased tenascin deposition in human cartilage with OA lesions [49]. The correlation between TN$\mathrm{C}$ and aggrecan loss could result from two different roles of TN-C: 1) TLR4 dependent TN-C induction of matrix degradation whereby $\mathrm{TN}-\mathrm{C}$ regulates the expression metalloproteases and 2) Loss of TN-C along with degraded fragments of aggrecan resulting from aggrecanase activity in diseased cartilage as TN-C binds to the alternatively spliced G3 domain of aggrecan [50]. Our results suggest an important role for TLR4 in the pathological process initiated by elevated TN-C in the diseased joints; testing TAK242 in the rat meniscal tear model of OA might provide additional information.

Increased intensity of $\mathrm{TN}-\mathrm{C}$ staining has been observed in areas of damaged human OA cartilage compared with normal cartilage [51], and a strong correlation between joint fluid TN-C levels and OA severity has also been reported [14]. A role for TN-C in the assembly of the chondrocyte matrix has been reported [52]. Treatment of human articular chondrocytes with TN-C was also shown to accelerate chondrocyte proliferation and play a role in cartilage repair [49]. These findings suggest involvement of TN-C in tissue remodeling that occurs in conjunction with degeneration and repair, which is further emphasized by the delay in articular cartilage repair observed for $\mathrm{TN}$-C-deficient 


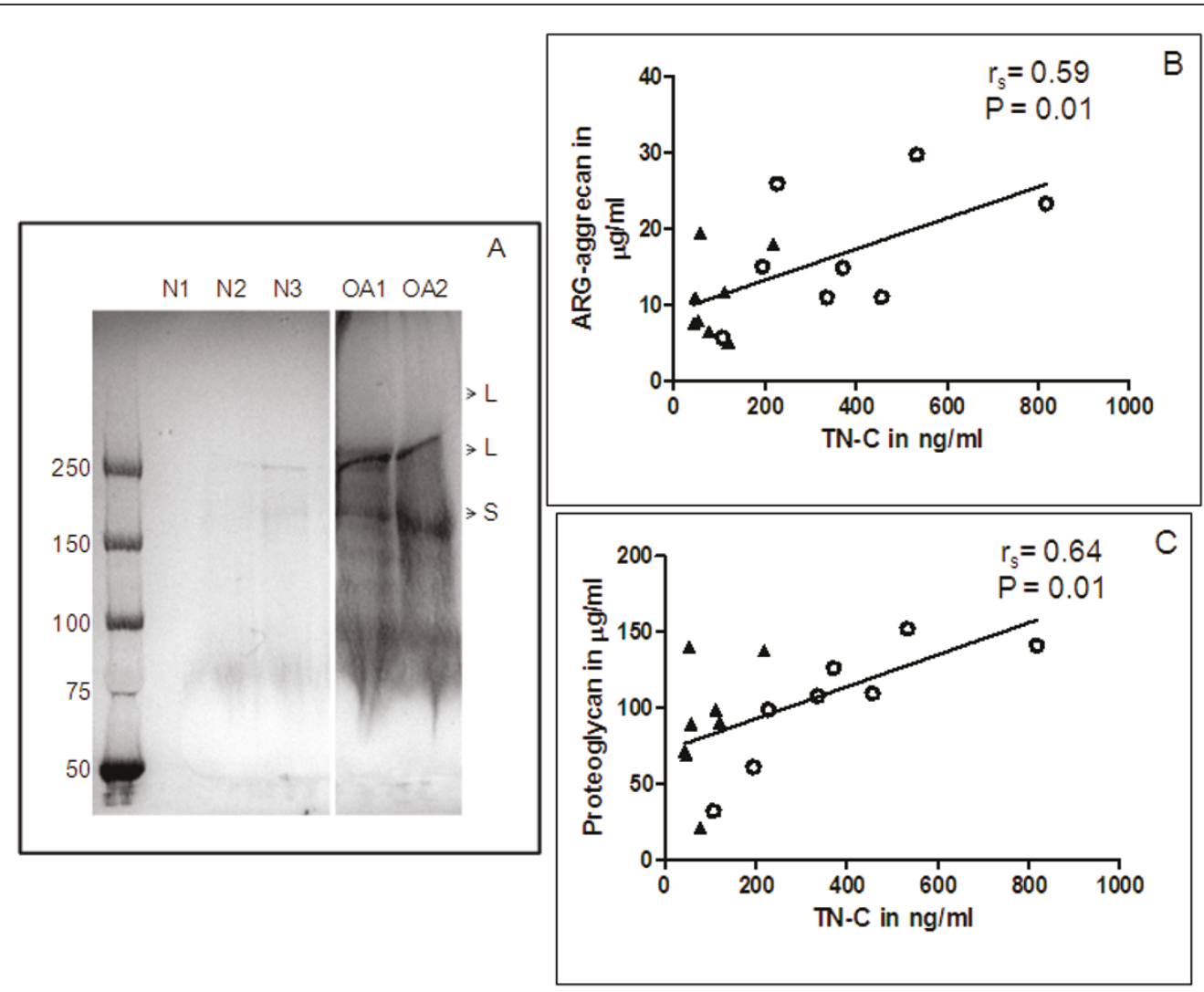

Figure $7 \mathrm{TN}-\mathrm{C}$ in human synovial fluids and its correlation to proteoglycan release. A, Western blot analysis of human synovial fluid. Representative samples (15 $\mu$ l each) were treated with $10 \mathrm{U}$ of hyaluronidase overnight at RT, separated on a 3-8\% tris-acetate gel, transferred, and probed with anti-TN-C (EGF-like domain) antibody, 4F10TT that detects all forms of TN-C. Lanes are N = synovial fluid of non-OA reference subjects; $\mathrm{O}=$ synovial fluid of $\mathrm{OA}$ patients. Bands are marked as $\mathrm{L}$ for large variants and $\mathrm{S}$ for small variants. $\mathrm{B}$, Correlation analysis of TN-C vs. ARG-aggrecan in human synovial fluid. C, Correlation analysis of TN-C vs. total proteoglycan in human synovial fluid. For both $B$ and $C, N=8$ each group; triangles represent non-OA reference subjects and circles represent OA patients.

mice [53]. Indeed, we observed a pronounced increase in $\mathrm{TN}-\mathrm{C}$ release into the joint fluid immediately after surgery in the rat model of OA/joint injury (Figure 8); TN-C levels decreased with time after surgery, indicating the transient expression of $\mathrm{TN}-\mathrm{C}$ during the repair process. Similar patterns of TN-C release with a pronounced increase immediately after injury/disease onset

Table 1 Correlation analysis of TN-C protein and mRNA in cartilage vs. TN-C protein in synovial fluid of $O A$ patients

\begin{tabular}{ccc}
\hline & $\begin{array}{c}\text { TN-C protein in } \\
\text { cartilage }\end{array}$ & $\begin{array}{c}\text { TN-C protein in } \\
\text { SF }\end{array}$ \\
\hline TN-C mRNA in cartilage & $r_{s}=0.9286$ & $r_{s}=0.8080$ \\
& $P=0.0005$ & $P=0.0059$ \\
\hline TN-C protein in & & $r_{s}=0.8696$ \\
cartilage & & $P=0.0022$ \\
\hline
\end{tabular}

Note: TN-C in the synovial was measured in the ELISA that quantifies only large variants of TN-C. SF: synovial fluid; $\mathrm{N}=7$ each from the same

individuals; Spearman rank order was used for correlation analysis; P indicates $\mathrm{p}$ values. that gradually reduced over time was observed when human knee synovial fluids from acute cruciate ligament injury, meniscal injury, and acute inflammatory arthritis patients were tested (data not shown).

We hypothesize that TN-C which reappears to attempt repair and remodeling in the OA joint could induce cytokines, inflammatory mediators, and matrix degrading enzymes and result in propagation of inflammation and matrix degradation through TLR4 signaling. TLR4 expression has been shown to increase in human OA cartilage lesions, and TLR4 ligands strongly induce catabolic responses in human chondrocytes including production of MMPs 1, 3, and 13 and of nitric oxide (NO), and PGE2, as well as a significant increase in the release of proteoglycan and type II collagen degraded products; treatment with TLR4 ligands led to phosphorylation of p38, ERK, and JNK, and activation of NF $\kappa \mathrm{B}$ [54]. The active domain of TN-C that activates cells in the joint has been mapped to the fibrinogen-like globe of the molecule [19]. Stimulation of cytokines in 


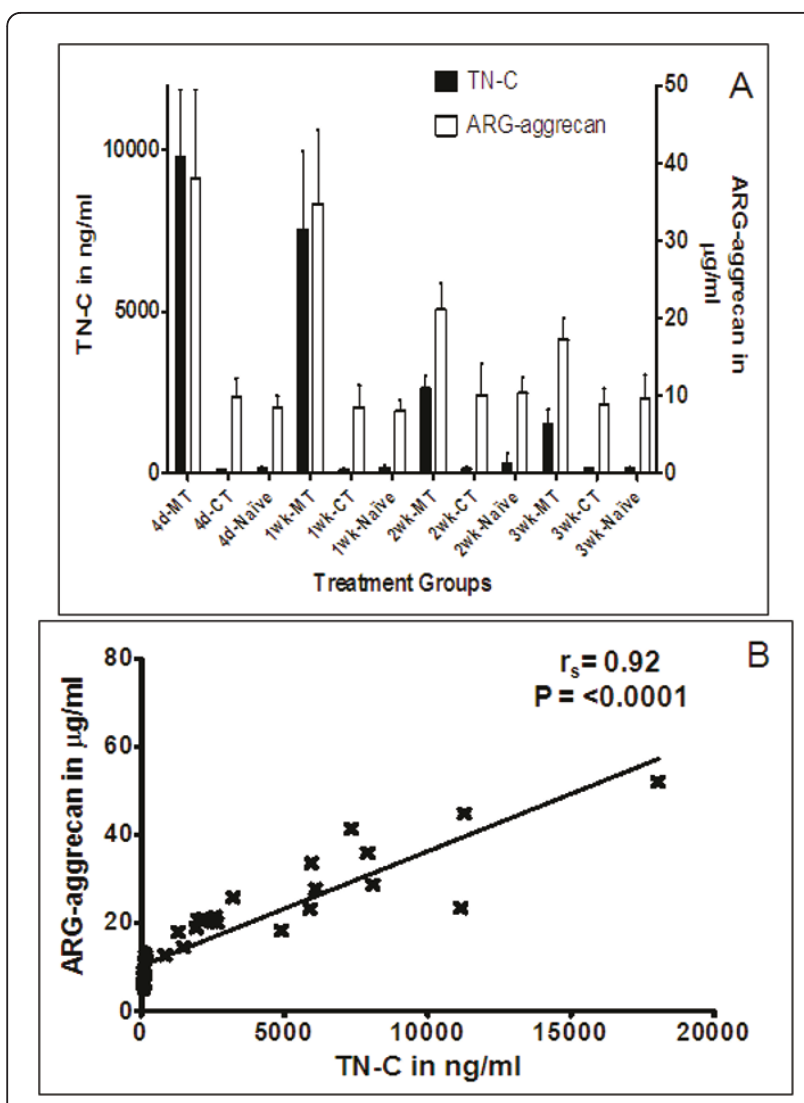

Figure $8 T N-C$ vs. ARG-aggrecan release in the rat meniscal tear model. A, Time course of TN-C vs. ARG-aggrecan release. Rats were euthanized at different times after surgery ( 4 days, 1 wk, 2 wks, and $3 \mathrm{wks} ; \mathrm{n}=10$ rats/time point). Five naïve rats (10 joints) per time point were included. For each time point, 10 synovial fluid lavage samples from the right meniscal tear (MT), left contra-lateral (CT), and naïve (left +right knees) joints were tested for TN-C and ARGaggrecan and values corrected for dilution using serum urea levels. Average values are shown with the error bars indicating SD. B, Correlation analysis of TN-C vs. ARG-aggrecan release in the rat meniscal tear model. TN-C and ARG-aggrecan data from the first five animals ( $n=5$ MT right knees and 5 CT left knees) of each time point ( 4 days, 1 wk, 2 wks, and 3 wks) were plotted in a correlation plot. Circles represent values from the $C T$ knees and crosses represent values from the MT knees ( $n=40 \mathrm{CT}$ and $40 \mathrm{MT}$ ).

synovial fibroblasts via activation of TLR4 was MyD88dependent [19]; MyD88 knockdown in human chondrocytes inhibited IL-1 induced expression of metalloproteases [55] suggesting MyD88 as a potential target in addition to TLR4 to intervene cartilage degradation. The rat meniscal tear model of $\mathrm{OA}$ and the $\mathrm{TN}-\mathrm{C}$ time course release pattern explored in this study could serve to evaluate TLR4 or MyD88 inhibitors, and in turn confirm the role of TLR4 signaling and TN-C in OA progression. Further studies to explore the signaling pathway of TN-C induced TLR4 in chondrocytes that leads to inflammation and cartilage matrix degradation are warranted.

\section{Conclusions}

TN-C mRNA and protein are upregulated in articular cartilage along with an increase in TN-C levels in the synovial fluid of OA patients. TN-C is inducible in primary chondrocytes by the inflammatory cytokine, IL-1; it is capable of stimulating further inflammatory mediators and promoting proteoglycan degradation in articular cartilage in vitro. $\mathrm{TN}-\mathrm{C}$ release into the joint fluid correlates with aggrecan loss in human and rat $\mathrm{OA}$ joints. De-novo expression of TN-C appears to be a reliable marker of joint injury/disease.

\section{List of Abbreviations}

TN-C: Tenascin-C; OA: osteoarthritis; IL-1: Interleukin-1; ECM: extracellular matrix; LPS: lipopolysaccharide; DAMP: damage-associated molecular pattern; EGF: epidermal growth factor; FN: fibronectin; RA: rheumatoid arthritis; TLR: Toll-like receptor; MMP: metalloprotease; PMB: polymyxin-B; Ref: knee-healthy reference subjects; $P \mathrm{PE}_{2}$ : Prostaglandin $\mathrm{E}_{2} ; \mathrm{SGAG}$ : sulfated glycosaminoglycan; LAL: Limulus amaebocyte lysate; EU: endotoxin units; IFN: interferon; TNFa: Tumor necrosis factor-a; bFGF: basic fibroblast growth factor; TGF $\beta$ : transforming growth factor- $\beta$; NO: nitric oxide; ERK: extracellular signalregulated kinase; JNK: c-Jun N-terminal kinase; NFKB: nuclear factor kappalight-chain-enhancer of activated B cells; SF: synovial fluid; CT: contralateral; MT: meniscal.

\section{Acknowledgements}

The authors thank Dr. J. Perry Hall, Inflammation for useful discussions and comments on the study; Dr. Zhiyong Yang and Dr. Katy E. Georgiadis for human cartilage and synovial fluid samples; Dr. Moises Rivera-Bermudez, Tracey Blanchet, Julio Tejada, and Comparative Medicine group of Pfizer for rat synovial fluids; Dr. Howard Seeherman, CSO of Tissue Repair, Pfizer for program support and New England Baptist Hospital (NEBH), Boston for human cartilage specimens.

\section{Authors' contributions}

LP was primarily responsible for the experimental set up, data acquisition and analysis, and contributed to manuscript preparation. WS performed Western blot analysis, ARG-aggrecan ELISA, and some human chondrocyte experiments. SSG was responsible for the rat model and related samples. EAM contributed to the concept of the study. CRF provided input on the experimental design and approved the manuscript. PSC was responsible for the conception and design of the study, data acquisition, analysis and interpretation, and manuscript design and preparation. All authors read and approved the final manuscript.

\section{Competing interests}

LP has no competing interests. WS, SSG, EAM, CRF, and PSC are current or past employees of Pfizer and hold company stocks/stock options.

Received: 23 March 2011 Accepted: 15 July 2011

Published: 15 July 2011

\section{References}

1. Chiquet-Ehrismann $\mathrm{R}$, Chiquet M: Tenascins: regulation and putative functions during pathological stress. J Pathol 2003, 200:488-499.

2. Mackie EJ, Thesleff I, Chiquet-Ehrismann R: Tenascin is associated with chondrogenic and osteogenic differentiation in vivo and promotes chondrogenesis in vitro. J Cell Biol 1987, 105:2569-2579.

3. Mackie EJ, Tucker RP: Tenascin in bone morphogenesis: expression by osteoblasts and cell type-specific expression of splice variants. J Cell Sci 1992, 103(Pt 3):765-771.

4. Jones FS, Hoffman S, Cunningham BA, Edelman GM: A detailed structural model of cytotactin: protein homologies, alternative RNA splicing, and binding regions. Proc Natl Acad Sci USA 1989, 86:1905-1909.

5. Midwood KS, Orend G: The role of tenascin-C in tissue injury and tumorigenesis. J Cell Commun Signal 2009, 3:287-310. 
6. Chiquet-Ehrismann R, Mackie EJ, Pearson CA, Sakakura T: Tenascin: an extracellular matrix protein involved in tissue interactions during fetal development and oncogenesis. Cell 1986, 47:131-139.

7. Yoshida T, Yoshimura E, Numata H, Sakakura $Y$, Sakakura $T$ : Involvement of tenascin- $C$ in proliferation and migration of laryngeal carcinoma cells. Virchows Arch 1999, 435:496-500.

8. Mackie EJ, Murphy LI: The role of tenascin-C and related glycoproteins in early chondrogenesis. MicrosC Res Tech 1998, 43:102-110.

9. Pacifici M, Iwamoto M, Golden EB, Leatherman JL, Lee YS, Chuong CM: Tenascin is associated with articular cartilage development. Dev Dyn 1993, 198:123-134

10. Chevalier X, Groult N, Larget-Piet B, Zardi L, Hornebeck W: Tenascin distribution in articular cartilage from normal subjects and from patients with osteoarthritis and rheumatoid arthritis. Arthritis Rheum 1994, 37:1013-1022.

11. Veje K, Hyllested-Winge $J$, Ostergaard K: Topographic and zonal distribution of tenascin in human articular cartilage from femoral heads: normal versus mild and severe osteoarthritis. Osteoarthritis Cartilage 2003, 11:217-227.

12. Salter $\mathrm{DM}$ : Tenascin is increased in cartilage and synovium from arthritic knees. Br J Rheumatol 1993, 32:780-786.

13. Goh FG, Piccinini AM, Krausgruber T, Udalova IA, Midwood KS: Transcriptional regulation of the endogenous danger signal tenascin-C: a novel autocrine loop in inflammation. J Immunol 2010, 184:2655-2662.

14. Schmidt-Rohlfing B, Gavenis K, Kippels M, Schneider U: New potential markers for cartilage degradation of the knee joint. Scand J Rheumatol 2002, 31:151-157.

15. Hasegawa M, Hirata H, Sudo A, Kato K, Kawase D, Kinoshita N, Yoshida T, Uchida A: Tenascin-C concentration in synovial fluid correlates with radiographic progression of knee osteoarthritis. J Rheumatol 2004, 31:2021-2026.

16. Abdollahi-Roodsaz $\mathrm{S}$, Joosten LA, Koenders MI, van den Brand $B T$, van de Loo FA, van den Berg WB: Local interleukin-1-driven joint pathology is dependent on toll-like receptor 4 activation. Am J Pathol 2009, 175:2004-2013.

17. Bobacz K, Sunk IG, Hofstaetter JG, Amoyo L, Toma CD, Akira S, Weichhart T, Saemann M, Smolen JS: Toll-like receptors and chondrocytes: the lipopolysaccharide-induced decrease in cartilage matrix synthesis is dependent on the presence of toll-like receptor 4 and antagonized by bone morphogenetic protein 7. Arthritis Rheum 2007, 56:1880-1893.

18. Kittlick PD, Engelmann D: Effect of the microbial constituents, LPS and BCG, on the glycosaminoglycans of chondrocyte cultures. Exp Pathol 1991, 42:145-150.

19. Midwood K, Sacre S, Piccinini AM, Inglis J, Trebaul A, Chan E, Drexler S, Sofat $\mathrm{N}$, Kashiwagi M, Orend G, Brennan F, Foxwell B: Tenascin-C is an endogenous activator of Toll-like receptor 4 that is essential for maintaining inflammation in arthritic joint disease. Nat Med 2009, 15:774-780.

20. Kanayama M, Kurotaki D, Morimoto J, Asano T, Matsui $Y$, Nakayama $Y$, Saito Y, Ito K, Kimura C, Iwasaki N, Suzuki K, Harada T, Li HM, Uehara J, Miyazaki T, Minami A, Kon S, Uede T: Alpha9 integrin and its ligands constitute critical joint microenvironments for development of autoimmune arthritis. J Immunol 2009, 182:8015-8025.

21. LaVallie ER, Chockalingam PS, Collins-Racie LA, Freeman BA, Keohan CC, Leitges M, Dorner AJ, Morris EA, Majumdar MK, Arai M: Protein kinase Czeta is up-regulated in osteoarthritic cartilage and is required for activation of NF-kappaB by tumor necrosis factor and interleukin-1 in articular chondrocytes. J Biol Chem 2006, 281:24124-24137.

22. Chockalingam PS, Varadarajan U, Sheldon R, Fortier E, LaVallie ER, Morris EA, Yaworsky PJ, Majumdar MK: Involvement of protein kinase Czeta in interleukin-1 beta induction of ADAMTS-4 and type 2 nitric oxide synthase via NF-kappaB signaling in primary human osteoarthritic chondrocytes. Arthritis Rheum 2007, 56:4074-4083.

23. Ii M, Matsunaga N, Hazeki K, Nakamura K, Takashima K, Seya T, Hazeki O, Kitazaki T, lizawa Y: A novel cyclohexene derivative, ethyl (6R)-6-[N-(2Chloro-4-fluorophenyl)sulfamoyl]cyclohex-1-ene-1-carboxylate (TAK-242), selectively inhibits toll-like receptor 4-mediated cytokine production through suppression of intracellular signaling. Mol Pharmacol 2006, 69:1288-1295.

24. Janusz MJ, Bendele AM, Brown KK, Taiwo YO, Hsieh L, Heitmeyer SA: Induction of osteoarthritis in the rat by surgical tear of the meniscus:
Inhibition of joint damage by a matrix metalloproteinase inhibitor. Osteoarthritis Cartilage 2002, 10:785-791.

25. Imanaka-Yoshida K, Hiroe M, Yasutomi Y, Toyozaki T, Tsuchiya T, Noda N, Maki T, Nishikawa T, Sakakura T, Yoshida T: Tenascin-C is a useful marker for disease activity in myocarditis. J Pathol 2002, 197:388-394.

26. Chockalingam PS, Sun W, Rivera-Bermudez MA, Zeng W, Dufield DR, Larsson S, Lohmander LS, Flannery CR, Glasson SS, Georgiadis KE, Morris EA: Elevated aggrecanase activity in a rat model of joint injury is attenuated by an aggrecanase specific inhibitor. Osteoarthritis Cartilage 2011, 19:315-323.

27. Tsunoda T, Inada H, Kalembeyi I, Imanaka-Yoshida K, Sakakibara M, Okada R, Katsuta K, Sakakura T, Majima Y, Yoshida T: Involvement of large tenascinC splice variants in breast cancer progression. Am J Pathol 2003, 162:1857-1867.

28. Farndale RW, Sayers CA, Barrett AJ: A direct spectrophotometric microassay for sulfated glycosaminoglycans in cartilage cultures. Connect Tissue Res 1982, 9:247-248.

29. Bjornsson S: Quantitation of proteoglycans as glycosaminoglycans in biological fluids using an alcian blue dot blot analysis. Anal Biochem 1998, 256:229-237.

30. Hasegawa M, Nakoshi Y, Muraki M, Sudo A, Kinoshita N, Yoshida T, Uchida A: Expression of large tenascin-C splice variants in synovial fluid of patients with rheumatoid arthritis. J Orthop Res 2007, 25:563-568.

31. Rettig WJ, Erickson HP, Albino AP, Garin-Chesa P: Induction of human tenascin (neuronectin) by growth factors and cytokines: cell typespecific signals and signalling pathways. J Cell Sci 1994, 107(Pt 2):487-497.

32. Pearson CA, Pearson D, Shibahara S, Hofsteenge J, Chiquet-Ehrismann R: Tenascin: cDNA cloning and induction by TGF-beta. Embo J 1988, 7:2977-2982

33. Tucker RP, Hammarback JA, Jenrath DA, Mackie EJ, Xu Y: Tenascin expression in the mouse: in situ localization and induction in vitro by bFGF. J Cell Sci 1993, 104(Pt 1):69-76.

34. Jenniskens YM, Koevoet W, de Bart AC, Weinans $H$, Jahr $H$, Verhaar JA, DeGroot J, van Osch GJ: Biochemical and functional modulation of the cartilage collagen network by IGF1, TGFbeta2 and FGF2. Osteoarthritis Cartilage 2006, 14:1136-1146.

35. Jones $\mathrm{PL}$, Jones FS: Tenascin-C in development and disease: gene regulation and cell function. Matrix Biol 2000, 19:581-596.

36. Siri A, Knauper V, Veirana N, Caocci F, Murphy G, Zardi L: Different susceptibility of small and large human tenascin-C isoforms to degradation by matrix metalloproteinases. J Biol Chem 1995, 270:8650-8654

37. Chevalier X, Claudepierre P, Groult N, Godeau GJ: Influence of interleukin 1 beta on tenascin distribution in human normal and osteoarthritic cartilage: a quantitative immunohistochemical study. Ann Rheum Dis 1996, 55:772-775.

38. Drexler SK, Sacre SM, Foxwell BM: Toll-like receptors: a new target in rheumatoid arthritis? Expert Rev Clin Immunol 2006, 2:585-599.

39. Akira S, Uematsu S, Takeuchi O: Pathogen recognition and innate immunity. Cell 2006, 124:783-801.

40. O'Neill LA: When signaling pathways collide: positive and negative regulation of toll-like receptor signal transduction. Immunity 2008, 29:12-20.

41. Tamaki Y, Takakubo Y, Hirayama T, Konttinen YT, Goodman SB, Yamakawa M, Takagi M: Expression of Toll-like Receptors and Their Signaling Pathways in Rheumatoid Synovitis. J Rheumatol 2011.

42. Kuroki K, Stoker AM, Sims HJ, Cook JL: Expression of Toll-like receptors 2 and 4 in stifle joint synovial tissues of dogs with or without osteoarthritis. Am J Vet Res 2010, 71:750-754.

43. Takashima K, Matsunaga N, Yoshimatsu M, Hazeki K, Kaisho T, Uekata M, Hazeki O, Akira S, lizawa Y, li M: Analysis of binding site for the novel small-molecule TLR4 signal transduction inhibitor TAK-242 and its therapeutic effect on mouse sepsis model. Br J Pharmacol 2009, 157:1250-1262.

44. Pratta MA, Yao W, Decicco C, Tortorella MD, Liu RQ, Copeland RA, Magolda R, Newton RC, Trzaskos JM, Arner EC: Aggrecan protects cartilage collagen from proteolytic cleavage. J Biol Chem 2003, 278:45539-45545.

45. Sandy JD, Verscharen C: Analysis of aggrecan in human knee cartilage and synovial fluid indicates that aggrecanase (ADAMTS) activity is responsible for the catabolic turnover and loss of whole aggrecan 
whereas other protease activity is required for C-terminal processing in vivo. Biochem J 2001, 358:615-626.

46. Tortorella MD, Malfait AM, Deccico C, Arner E: The role of ADAM-TS4 (aggrecanase-1) and ADAM-TS5 (aggrecanase-2) in a model of cartilage degradation. Osteoarthritis Cartilage 2001, 9:539-552.

47. Moulharat N, Lesur C, Thomas M, Rolland-Valognes G, Pastoureau P, Anract $P$, De Ceuninck F, Sabatini M: Effects of transforming growth factor-beta on aggrecanase production and proteoglycan degradation by human chondrocytes in vitro. Osteoarthritis Cartilage 2004, 12:296-305.

48. Tremble P, Chiquet-Ehrismann R, Werb Z: The extracellular matrix ligands fibronectin and tenascin collaborate in regulating collagenase gene expression in fibroblasts. Mol Biol Cell 1994, 5:439-453.

49. Nakoshi $Y$, Hasegawa M, Akeda K, lino T, Sudo A, Yoshida T, Uchida A: Distribution and role of tenascin-C in human osteoarthritic cartilage. J Orthop Sci 2010, 15:666-673.

50. Day JM, Olin Al, Murdoch AD, Canfield A, Sasaki T, Timpl R, Hardingham TE, Aspberg A: Alternative splicing in the aggrecan $G 3$ domain influences binding interactions with tenascin- $C$ and other extracellular matrix proteins. J Biol Chem 2004, 279:12511-12518.

51. Nakoshi Y, Hasegawa M, Sudo A, Yoshida T, Uchida A: Regulation of tenascin-C expression by tumor necrosis factor-alpha in cultured human osteoarthritis chondrocytes. J Rheumatol 2008, 35:147-152.

52. Savarese JJ, Erickson H, Scully SP: Articular chondrocyte tenascin-C production and assembly into de novo extracellular matrix. J Orthop Res 1996, 14:273-281.

53. Okamura N, Hasegawa M, Nakoshi $Y$, lino $T$, Sudo A, Imanaka-Yoshida $K$, Yoshida T, Uchida A: Deficiency of tenascin-C delays articular cartilage repair in mice. Osteoarthritis Cartilage 2010, 18:839-848.

54. Kim HA, Cho ML, Choi HY, Yoon CS, Jhun JY, Oh HJ, Kim HY: The catabolic pathway mediated by Toll-like receptors in human osteoarthritic chondrocytes. Arthritis Rheum 2006, 54:2152-2163.

55. Ahmad R, Sylvester J, Zafarullah M: MyD88, IRAK1 and TRAF6 knockdown in human chondrocytes inhibits interleukin-1-induced matrix metalloproteinase-13 gene expression and promoter activity by impairing MAP kinase activation. Cell Signal 2007, 19:2549-2557.

\section{Pre-publication history}

The pre-publication history for this paper can be accessed here: http://www.biomedcentral.com/1471-2474/12/164/prepub

doi:10.1186/1471-2474-12-164

Cite this article as: Patel et al:: Tenascin- $\mathrm{C}$ induces inflammatory mediators and matrix degradation in osteoarthritic cartilage. BMC Musculoskeletal Disorders 2011 12:164.

\section{Submit your next manuscript to BioMed Central and take full advantage of:}

- Convenient online submission

- Thorough peer review

- No space constraints or color figure charges

- Immediate publication on acceptance

- Inclusion in PubMed, CAS, Scopus and Google Scholar

- Research which is freely available for redistribution

Submit your manuscript at www.biomedcentral.com/submit
C Biomed Central 